\title{
Dose-Dependent Protective and Inductive Effects of Xanthohumol on Oxidative DNA Damage in Saccharomyces cerevisiae
}

\author{
Daniel O. Carvalho ${ }^{1}$, Rui Oliveira ${ }^{2}$, Björn Johansson ${ }^{3}$ and Luís F. Guido ${ }^{1 *}$ \\ ${ }^{1}$ REQUIMTE/LAQV - Department of Chemistry and Biochemistry, Faculty of Sciences, \\ University of Porto, Rua do Campo Alegre 687, PT-4169-007 Porto, Portugal \\ ${ }^{2}$ Center for the Research and Technology of Agro-Environmental and Biological Sciences (CITAB), \\ Department of Biology, University of Minho, Campus de Gualtar, PT-4710-057 Braga, Portugal \\ ${ }^{3}$ Centre of Molecular and Environmental Biology (CBMA), Department of Biology, \\ University of Minho, Campus de Gualtar, PT-4710-057 Braga, Portugal
}

Received: May 13, 2015

Accepted: October 27, 2015

\begin{abstract}
Summary
The effect of xanthohumol, a prenylflavonoid isolated from the hop plant (Humulus lupulus L.), on Saccharomyces cerevisiae DNA oxidative damage and viability was evaluated. Yeast cultures under oxidative stress, induced by $\mathrm{H}_{2} \mathrm{O}_{2}$, displayed stronger growth in the presence of $5 \mathrm{mg} / \mathrm{L}$ of xanthohumol than cultures with only $\mathrm{H}_{2} \mathrm{O}_{2}$. Likewise, DNA damage assessed by the comet assay was significantly lower in cells co-incubated with xanthohumol and $\mathrm{H}_{2} \mathrm{O}_{2}$. Accordingly, fluorescence of dichlorofluorescein in cells treated with $\mathrm{H}_{2} \mathrm{O}_{2}$ and xanthohumol was considerably lower than in cells exclusively treated with $\mathrm{H}_{2} \mathrm{O}_{2}$, indicative of a reactive oxygen species scavenging mechanism and consequent formation of oxidation products, as detected by mass spectrometry. However, at concentrations above 5 $\mathrm{mg} / \mathrm{L}$, xanthohumol elicited an opposite effect, leading to a slower growth rate and significant increase in DNA damage. A yeast yap1 deletion mutant strain sensitive to oxidative stress grew more slowly in the presence of at least $5 \mathrm{mg} / \mathrm{L}$ of xanthohumol than cultures of the wild type, suggesting that xanthohumol toxicity is mediated by oxidative stress. This evidence provides further insight into the impact of xanthohumol on yeast cells, supporting dose-dependent antioxidant/antigenotoxic and prooxidant/genotoxic effects.
\end{abstract}

Key words: genotoxic and antigenotoxic effects, antioxidant and prooxidant capacity, comet assay, Saccharomyces cerevisiae, xanthohumol, yeast viability

\section{Introduction}

The prenylated chalcone xanthohumol ((E)-1-[2,4-dihydroxy-6-methoxy-3-(3-methylbut-2-enyl)phenyl]-3-(4-hydroxyphenyl)prop-2-en-1-one) is the principal prenylflavonoid of the female inflorescences (hops) of the hop plant Humulus lupulus L. $(1,2)$. Hops are used in beer production to add bitterness and flavour, whereby beer is the main human dietary source of xanthohumol $(3,4)$. This phenolic compound has received considerable attention in recent years, since it has shown interesting biological properties with potential for disease prevention and therapeutic applications: anti-inflammatory, antioxidant, antilipoperoxidative activities as well as antiangiogenic and antiproliferative effects (3-5).

Xanthohumol has been shown to exhibit potent antioxidant activity through the direct scavenging of reactive oxygen species (ROS) generated by xanthine oxidase, while 
its isomer isoxanthohumol is inactive (6). The radicals formed by oxidative stress can modify polyunsaturated lipids, proteins and nucleic acids, and are therefore associated with the early stages of carcinogenesis and apoptosis (4). Xanthohumol can also inhibit $\mathrm{Cu}^{2+}$-mediated oxidation of low-density lipoproteins, but also promote oxidation by accelerating the formation of hydroxyl radicals in mixtures with $\mathrm{H}_{2} \mathrm{O}_{2}(7,8)$. The capacity of xanthohumol to induce intracellular ROS was shown to activate the mitochondrial apoptotic pathway in human malignant glioblastoma cells (9). Other studies support this finding, showing that it is able to inhibit the growth and to induce apoptosis in several cancer cell lines: prostate (10), ovarian (11), glioblastoma and malignant astrocytes $(9,12)$, lymphocytic leukaemia (13) and colon (14).

The brewing industry has been particularly attentive to the health-promoting properties of xanthohumol aiming at the production of xanthohumol-enriched beer. The fermentation process is responsible for a strong reduction of xanthohumol content, since almost $60-90 \%$ of it is lost by adsorption to Saccharomyces cerevisiae cells $(15,16)$, which explains the relatively low xanthohumol content found in commercial beer. Therefore, different studies have focused on the evaluation of the parameters responsible for the decrease of xanthohumol in beer and how to overcome this problem to obtain its higher levels in the final product. However, in order to maintain the overall organoleptic properties and quality of the final beer, it is important to understand how the increased xanthohumol content might affect $S$. cerevisiae physiology. Yeast cells produce ROS as a by-product of oxidative phosphorylation, which can affect fermentation performance as well as the oxidative stability of the final beer (17). Xanthohumol has recently been shown to exhibit a dose-dependent effect on mitochondria of mammalian cells (18). Thus, the potential problems or benefits that it could bring to yeast physiology, due to its antioxidant properties, is an important issue of brewing research. A recent study, developed at pilot-scale, showed that xanthohumol has a positive dose-dependent effect on the physiological conditions of brewer's yeast during fermentation (19).

The aim of the present work is to reveal how xanthohumol may affect the yeast cell viability in order to allow improvements of the brewing process such as efficiency of fermentation and production of xanthohumol-enriched beer. We have investigated the mechanism of action of xanthohumol on the yeast cells by assessing its intracellular antioxidant activity using flow cytometry with dichlorofluorescein diacetate $\left(\mathrm{H}_{2} \mathrm{DCFDA}\right)$. The in vitro antioxidant capacity of xanthohumol was also evaluated using the metmyoglobin antioxidant assay, based on the capacity to inhibit the ABTS ( 2,2 '-azino-di-[3-ethylbenzthiazoline sulphonate]) radical formation by metmyoglobin. Finally, the antigenotoxic/genotoxic effects of xanthohumol on yeast cells were investigated using the yeast comet assay to assess oxidative DNA damage.

\section{Material and Methods}

\section{Reagents and standards}

All the reagents used, except when otherwise stated, were purchased from GIBCO (Paisley, Scotland) and were of analytical grade. High-purity water (resistivity not lower than $18.2 \mathrm{M} \Omega \cdot \mathrm{cm}$ ) from a Direct- $\mathrm{Q}^{\circledR} 3 \mathrm{UV}$ water purification system (Millipore Iberica, S.A., Madrid, Spain) was used for all analyses. Xanthohumol (>98\% purity) was kindly donated by Martin Biendl from Hopsteiner (S. S. Steiner, New York, NY, USA, and Steiner Hopfen $\mathrm{GmbH}$, Mainburg, Germany). Dichlorofluorescein diacetate $\left(\mathrm{H}_{2} \mathrm{DCFDA}\right)$ was purchased from Life Technologies (Carlsbad, CA, USA), $\mathrm{H}_{2} \mathrm{O}_{2}(30 \%)$ was purchased from Merck (Darmstadt, Germany), quercetin (>98\%) and anhydrous ethanol, used as solvent, were purchased from Sigma-Aldrich (St. Louis, MO, USA). Acetonitrile (high-performance liquid chromatography grade) and formic acid (for mass spectrometry) were obtained from Sigma-Aldrich. Xanthohumol and quercetin stock solutions of 1 $\mathrm{g} / \mathrm{L}$ were prepared by diluting the appropriate amount of reagent in ethanol and were stored at $-20{ }^{\circ} \mathrm{C}$. These solutions were used to prepare diluted solutions in all experiments.

\section{Yeast strains, media and culture conditions}

Two Saccharomyces cerevisiae strains were used in this

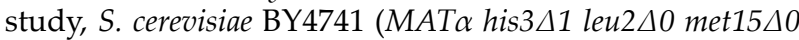
ura3 $\Delta 0$ ) and yap1, which is the same strain also carrying the yap1(YKL114c)::kanMX4 replacement allele. Both were obtained from the European Saccharomyces cerevisiae Archive for Functional Analysis (EUROSCARF, Institute for Molecular Biosciences, Johann Wolfgang Goethe-University Frankfurt, Frankfurt, Germany). Stock cultures were maintained on solid YPD medium (containing in \% by mass per volume: yeast extract 1 , peptone 2 , glucose 2 and agar 2) at $30{ }^{\circ} \mathrm{C}$ for 2 days and then maintained at 4 ${ }^{\circ} \mathrm{C}$ for one week. Cells were cultivated in liquid YPD medium (without agar), in an orbital shaker at $30^{\circ} \mathrm{C}$ and 200 $\mathrm{rpm}$. Growth was monitored by measuring the absorbance at $600 \mathrm{~nm}\left(A_{600 \mathrm{~nm}}\right)$.

\section{Yeast culture preparation}

Saccharomyces cerevisiae cells were removed with an inoculation loop from a solid stock culture, then suspended in $5 \mathrm{~mL}$ of YPD medium (pre-inoculum) and incubated overnight at $30{ }^{\circ} \mathrm{C}$ and $200 \mathrm{rpm}$. An appropriate volume of the pre-inoculum was diluted in fresh YPD medium to obtain $A_{600 \mathrm{~nm}}=0.1$ and the culture was incubated under the same conditions for two generations to reach $A_{600 \mathrm{~nm}}=0.4$. Subsequently, cells were harvested by centrifugation at $5000 \times g$ and $4{ }^{\circ} \mathrm{C}$ for $2 \mathrm{~min}$, washed once with the same volume of sterile deionised water and suspended in sterile deionised water, an appropriate buffer or liquid YPD medium depending on the experiment. This procedure ensures that cells are in an early exponential phase of growth.

\section{Viability assays}

A volume of $100 \mu \mathrm{L}$ of cell suspension was collected, serially diluted to $10^{-4}$ in sterile deionised water and 100 $\mu \mathrm{L}$ were spread on solid YPD medium in order to obtain the viability count before treatments. Next, different dilutions of xanthohumol were added to aliquots of the initial culture in YPD medium for final concentrations of 1, 5, 10, 20 and $50 \mathrm{mg} / \mathrm{L}$ (final volume of $1 \mathrm{~mL}$ was maintained in all samples). Alternatively, the solvent (ethanol) was added to similar cell suspensions for control. In all samples 
the maximum final ethanol volume fraction was $5 \%$. The suspensions were incubated at $30{ }^{\circ} \mathrm{C}$ and $200 \mathrm{rpm}$, and $100 \mu \mathrm{L}$ were taken from each aliquot at 30,60 and 150 min, diluted and spread on solid YPD. Cells were incubated at $30{ }^{\circ} \mathrm{C}$ for $48 \mathrm{~h}$ and the colonies were counted. Survival rates were calculated as percentage of colony-forming units (CFU), assuming $100 \%$ survival of cells before any treatment (ethanol or xanthohumol). In order to exclude the effect of cell proliferation in culture media in viability assays, the procedure of the viability assays was the same, except that the cells were suspended in phosphate-buffered saline (PBS; $137 \mathrm{mM} \mathrm{NaCl}, 2.7 \mathrm{mM} \mathrm{KCl}$, $4.3 \mathrm{mM} \mathrm{Na}_{2} \mathrm{HPO}_{4}$ and $1.47 \mathrm{mM} \mathrm{KH} \mathrm{PO}_{4}, \mathrm{pH}=7.4$ ) instead of sterile deionised water, after harvesting the culture, and all treatments were performed in PBS instead of YPD.

\section{Evaluation of the growth of yeast cultures}

An appropriate volume of the pre-inoculum was diluted in liquid YPD medium to achieve $A_{600 \mathrm{~nm}}=0.1$ as stated above and the culture was incubated with xanthohu$\mathrm{mol}(1,5,10,20$ or $50 \mathrm{mg} / \mathrm{L})$ and $10 \mathrm{mM} \mathrm{H}_{2} \mathrm{O}_{2}$. Ethanol (similar volume as xanthohumol solution) was added to a similar culture to be used as control. Cultures were incubated at $30{ }^{\circ} \mathrm{C}$ and $200 \mathrm{rpm}$, and growth was monitored by measuring the absorbance at $600 \mathrm{~nm}$ for $300 \mathrm{~min}$. Specific growth rate was calculated from periodical measures of $A_{600 \mathrm{~nm}}$.

\section{Comet assay}

The yeast comet assay was performed to quantitatively determine DNA damage as described by Oliveira and Johansson (20). The yeast culture was prepared as mentioned above, cells were harvested by centrifugation at $5000 \times g$ and $4{ }^{\circ} \mathrm{C}$ for $2 \mathrm{~min}$ and washed twice with the same volume of ice-cold deionised water. Cells were resuspended in $2 \mathrm{mg} / \mathrm{mL}$ of zymolyase $20 \mathrm{~T}$ (20 $000 \mathrm{U} / \mathrm{g}$; ImmunO $^{\mathrm{TM}}$, MP Biomedicals, LLC, Santa Ana, CA, USA) in $\mathrm{S}$ buffer (1 M sorbitol and $\left.25 \mathrm{mM} \mathrm{KH} \mathrm{PO}_{4}, \mathrm{pH}=6.5\right)$ containing $50 \mathrm{mM} \beta$-mercaptoethanol and incubated at $30^{\circ} \mathrm{C}$ and $200 \mathrm{rpm}$ for $30 \mathrm{~min}$, in order to obtain spheroplasts. Spheroplasts were collected by centrifugation at $5000 \times g$ and $4{ }^{\circ} \mathrm{C}$ for $2 \mathrm{~min}$, washed twice with the same volume of ice-cold $S$ buffer, resuspended in the same volume of $S$ buffer and distributed in aliquots of $100 \mu \mathrm{L}$. For treatments, aliquots of suspended cells were incubated for $20 \mathrm{~min}$ at $30^{\circ} \mathrm{C}$ in the presence of xanthohumol $(1,2,5,7.5,10$ or 20 $\mathrm{mg} / \mathrm{L}$ ), ethanol and $\mathrm{H}_{2} \mathrm{O}_{2}$ (positive control; $10 \mathrm{mM} \mathrm{H} \mathrm{O}_{2}$ and $5 \%$, by volume, ethanol), mixtures of xanthohumol and $\mathrm{H}_{2} \mathrm{O}_{2}(1,2,5$ or $10 \mathrm{mg} / \mathrm{L}$ of xanthohumol and $10 \mathrm{mM}$ $\mathrm{H}_{2} \mathrm{O}_{2}$ ) or ethanol (negative control; same volume as xanthohumol solution). For the assessment of genotoxicity, spheroplasts were incubated only with xanthohumol, and of antigenotoxicity with xanthohumol and $\mathrm{H}_{2} \mathrm{O}_{2}$. After incubation, spheroplasts were collected by centrifugation at $5000 \times g$ and $4{ }^{\circ} \mathrm{C}$ for $2 \mathrm{~min}$, washed twice with $\mathrm{S}$ buffer and then suspended in $50 \mu \mathrm{L}$ of low melting agarose $(1.5$ $\%$ by mass per volume in $\mathrm{S}$ buffer) at $35^{\circ} \mathrm{C}$. Subsequently, samples were analysed by the yeast comet assay as described elsewhere (20). At least 20 comets from representative images were acquired from each sample. The tail length $(\mu \mathrm{m})$ was measured using the CometScore v. 1.5 software (21) and used as a parameter for DNA damage quantification.

\section{Flow cytometry analysis}

The yeast culture was prepared as described in Yeast culture preparation section. Cells were harvested by centrifugation at $5000 \times g$ and $4{ }^{\circ} \mathrm{C}$ for $2 \mathrm{~min}$ and washed twice with the same volume of PBS. The suspension was diluted to reach $A_{600 \mathrm{~nm}}=0.02$ with PBS and $500 \mu \mathrm{L}$ were collected for autofluorescence measurement. The antioxidant activity was measured as described by Marques et al. (22) with minor modifications. Dichlorofluorescein diacetate $\left(\mathrm{H}_{2} \mathrm{DCFDA}\right)$ was added to the cell suspension (final concentration $50 \mu \mathrm{M}$ ) and cells were further incubated at $30^{\circ} \mathrm{C}$ and $200 \mathrm{rpm}$ for $1 \mathrm{~h}$ in the dark. Cells were washed twice with the same volume of PBS and aliquots of $1 \mathrm{~mL}$ were incubated with xanthohumol $(1,2$ or $5 \mathrm{mg} / \mathrm{L})$ and $5 \mathrm{mM}$ $\mathrm{H}_{2} \mathrm{O}_{2}$ for $20 \mathrm{~min}$ at $30^{\circ} \mathrm{C}$. Each sample containing 20000 cells was analysed by flow cytometry in an Epics ${ }^{\circledR}$ XLTM cytometer (Beckman Coulter, Brea, CA, USA) equipped with a $15 \mathrm{~mW}$ argon-ion laser emitting at $488 \mathrm{~nm}$. Green fluorescence was collected through a 488-nm blocking filter, a 550-nm long-pass dichroic and a 225-nm band-pass filter. Data were analysed and histograms were made with the FlowJo v. 10.0.7 software (23).

\section{HPLC-DAD-ESI-MS/MS analysis of xanthohumol oxidation products}

The identification of the oxidation products of xanthohumol was confirmed online by high-performance liquid chromatography with diode array detector (HPLC-DAD) coupled with electrospray ionization tandem mass spectrometry (ESI-MS/MS). The samples were prepared by adding $5 \mathrm{mM} \mathrm{H}_{2} \mathrm{O}_{2}$ to $10 \mathrm{mg} / \mathrm{L}$ of xanthohumol solution prepared in $10 \mathrm{mM}$ ammonium bicarbonate buffer at $\mathrm{pH}=7$. The mixture was incubated for $20 \mathrm{~min}$ at $30{ }^{\circ} \mathrm{C}$ in the dark. Control assays without $\mathrm{H}_{2} \mathrm{O}_{2}$ and/or xanthohumol were also prepared. The formation of oxidation products was investigated by HPLC-DAD-ESI-MS/MS. The HPLC Accela system was equiped with Accela PDA detector, Accela Autosampler and Accela 600 Pump (Thermo Fischer Scientific, Bremen, Germany). Separations were carried out on a Phenomenex Gemini $3 \mu \mathrm{m}$ C18 $100 \AA$ LC column, $150 \mathrm{~mm} \times 4.6 \mathrm{~mm}$ (Phenomenex Inc., Torrance, CA, USA) with a pre-column $(4 \mathrm{~mm} \times 3.0 \mathrm{~mm})$ using a binary solvent gradient (solvent A: $0.1 \%$ formic acid in water and solvent $\mathrm{B}$ : acetonitrile), starting the injection with $40 \%$ B, followed by a linear increase to $100 \%$ B in $20 \mathrm{~min}$ and maintained for $5 \mathrm{~min}$ under these conditions. The flow rate was $0.4 \mathrm{~mL} / \mathrm{min}$ and a total volume of $20 \mu \mathrm{L}$ of a sample was injected into the column, which was kept at $20^{\circ} \mathrm{C}$.

An LTQ Orbitrap XL mass spectrometer (Thermo Fischer Scientific) controlled by LTQ Tune Plus v. 2.5.5 software and equipped with an electrospray ionization (ESI) source was used. Simultaneous acquisition of mass spectral data and photodiode array (PDA) data was processed by using Xcalibur v. 2.2 software (24). The capillary voltage of the ESI was set to $3000 \mathrm{~V}$. The capillary temperature was $275{ }^{\circ} \mathrm{C}$. The sheath gas and auxiliary gas flow rate (nitrogen) were set to 40 and 10, respectively (arbitrary units as provided by the software settings). The capillary voltage was $9 \mathrm{~V}$ and the tube lens voltage $60 \mathrm{~V}$. Acquisition of the mass data was performed between $m / z=80$ 
and 2000 and the Orbitrap resolution was set to 30000 . All experiments were done using MSE (Waters, Milford, MA, USA) for data recording without discrimination of ions or their preselection (30.0 energy collision). The positive ion polarity mode was selected in this work due to a better signal-to-noise ratio in comparison with negative ion mode.

\section{Metmyoglobin antioxidant assay}

The Antioxidant Assay Kit was purchased from Cayman Chemical Company (Ann Harbor, MI, USA), and the assay was developed according to the manufacturer's protocol. The assay was performed in 96-well plates by adding to each well $10 \mu \mathrm{L}$ of xanthohumol or quercetin (0-200 mg/L), $10 \mu \mathrm{L}$ of metmyoglobin and $150 \mu \mathrm{L}$ of ABTS $^{+}$. At the end, $50 \mu \mathrm{L}$ of $\mathrm{H}_{2} \mathrm{O}_{2}(441 \mu \mathrm{M})$ were added to the mixture and incubated in a shaker for $5 \mathrm{~min}$ at room temperature. Antioxidant capacity was quantified by reading the absorbance at $750 \mathrm{~nm}$ using a BioTek ${ }^{\circledR}$ PowerWave XS (Winooski, VT, USA) microplate reader and evaluating the half maximal inhibitory concentration $\left(\mathrm{IC}_{50}\right)$ responsible for inhibition of $50 \%$ of ABTS oxidation.

\section{Statistical analysis}

Comet assay results are presented as the mean value \pm standard deviation (S.D.) obtained from at least 20 comets of each of three independent experiments. All other results are presented as the mean value \pm S.D. from at least three independent experiments. One-way analysis of variance (ANOVA) was used for comparison of more than two mean values and Tukey's test was used for multiple comparisons. Spearman's rank correlation coefficient $\left(r_{\mathrm{s}}\right)$ was applied to measure the strength of association between two ranked variables.

\section{Results}

\section{Effect of xanthohumol on yeast viability}

Yeast cells were incubated with xanthohumol (1, 5, 10,20 or $50 \mathrm{mg} / \mathrm{L}$ ) for different time periods, and then plated on solid YPD medium to evaluate the effect of xanthohumol on viability. This concentration range was chosen according to the suggested final xanthohumol concentration in enriched beer (up to $30 \mathrm{mg} / \mathrm{L}$ ) (25). A control without xanthohumol, but containing the same volume of the solvent (ethanol), was included in order to evaluate the viability of untreated and non-stressed cells. When yeast cells were exposed to xanthohumol concentrations equal to or higher than $10 \mathrm{mg} / \mathrm{L}$, a significant increase $(p>0.05)$ in the rate of loss of viability was observed (Fig. 1a), while concentrations equal to or lower than $5 \mathrm{mg} / \mathrm{L}$ did not have significant impact on the yeast viability. Incubation in the presence of PBS for $150 \mathrm{~min}$ led to substantially higher viabilities (Fig. 1b) compared to cultures in YPD (Fig. 1a), particularly in the presence of $20 \mathrm{mg} / \mathrm{L}$ of xanthohumol. This result strongly suggests that the toxic activity of xanthohumol is mediated by active yeast metabolism, which is attenuated in the nutrient-free PBS solution.
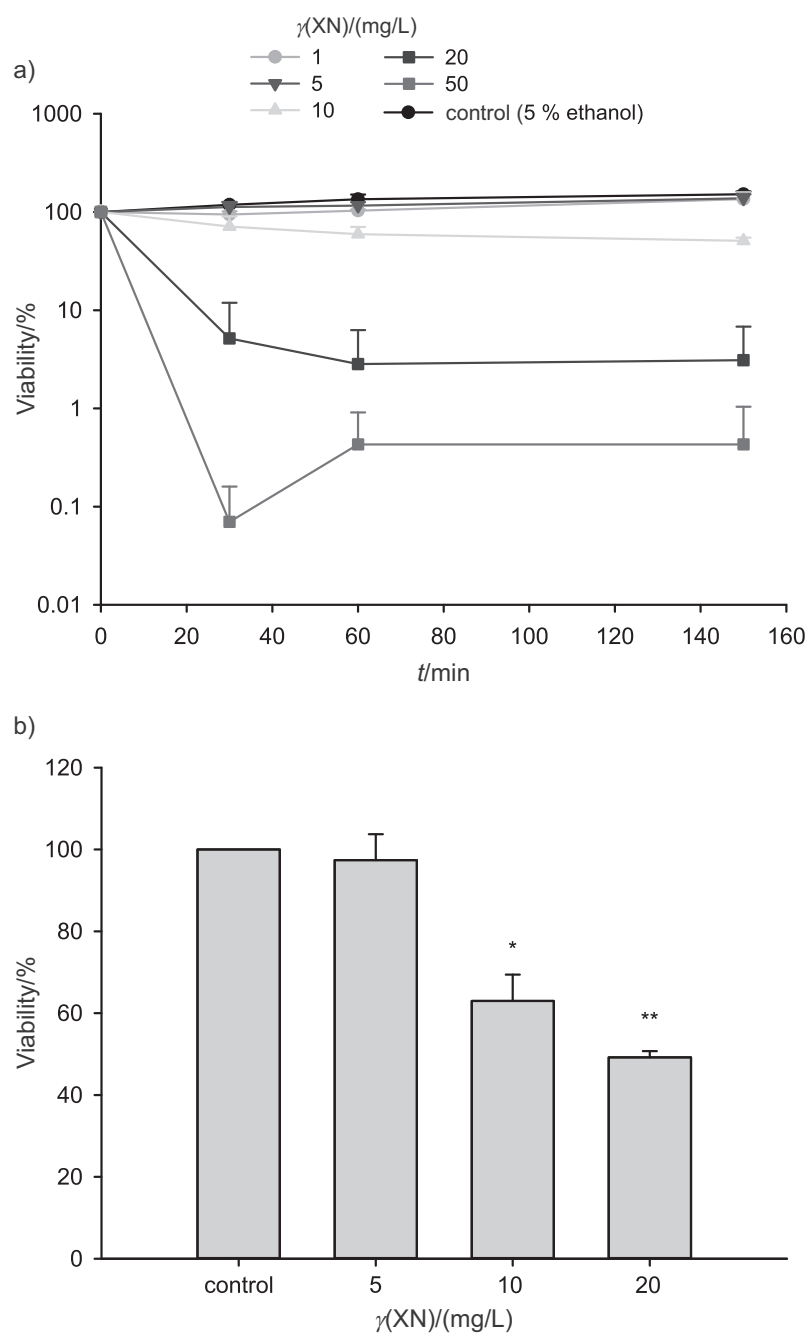

Fig. 1. Effect of xanthohumol (XN) on the viability of Saccharomyces cerevisiae BY4741 cells in: a) YPD cultures and in b) PBS suspensions. Yeast cells were incubated with XN or $5 \%$ (by volume) ethanol at each time point (150 min in Fig. b) aliquots were collected, diluted to $10^{-4}$ and spread on YPDA plates. Colonies were counted after $48 \mathrm{~h}$ of incubation at $30{ }^{\circ} \mathrm{C}$ and the percentage of viability was calculated taking $0 \mathrm{~min}$ as reference. Data are the mean value $\pm S$.D. of three independent experiments $\left({ }^{*} \mathrm{p}<0.05,{ }^{* *} \mathrm{p}<0.01\right)$

\section{Xanthohumol has in vitro antioxidant activity}

The antioxidant capacity of xanthohumol was tested by the metmyoglobin assay, a rapid method for the assessment of antioxidant protection of a substance $(26,27)$. This assay has been used to measure the total antioxidant capacity of various biological samples related to the production of ROS as a consequence of normal aerobic metabolism. The assay relies on the ability of compounds to inhibit the oxidation of ABTS to $\mathrm{ABTS}^{+}$by metmyoglobin. The amount of produced radical is suppressed to a given level, which is proportional to the antioxidant capacity of the tested compound. In this case, different xanthohumol concentrations were tested based on its antioxidant capacity and compared with quercetin, a naturally occurring polyphenol well-known for its antioxidant properties. Xanthohumol displayed a weak antioxidant capacity after the addition of $\mathrm{H}_{2} \mathrm{O}_{2}\left(\mathrm{IC}_{50}=31.47 \mathrm{mg} / \mathrm{L}\right)$ when com- 
pared to quercetin $\left(\mathrm{IC}_{50}=39.97 \mathrm{mg} / \mathrm{L}\right)$, which correlates with the decreased toxicity in cells suspended in PBS, presented above, where cellular metabolism is attenuated.

\section{Xanthohumol protects yeast cells under stress conditions}

The low antioxidant capacity of xanthohumol observed in the metmyoglobin assay could potentially protect yeast cells from oxidative stress. To test this hypothesis, we measured yeast growth in the presence of $10 \mathrm{mM}$ $\mathrm{H}_{2} \mathrm{O}_{2}$ with and without xanthohumol. As the xanthohumol is dissolved in $5 \%$ ethanol, the same volume fraction of ethanol without xanthohumol was included in the control. Yeast cultures did not grow in the presence of $10 \mathrm{mM}$ $\mathrm{H}_{2} \mathrm{O}_{2}$ (with $5 \%$ ethanol) or in combination with 1 or 2 $\mathrm{mg} / \mathrm{L}$ of xanthohumol (Fig. 2). The presence of $5 \mathrm{mg} / \mathrm{L}$ of xanthohumol had a protective effect against $\mathrm{H}_{2} \mathrm{O}_{2}$ as yeast growth could be observed after $120 \mathrm{~min}$ of incubation when compared with cultures containing $10 \mathrm{mM} \mathrm{H}_{2} \mathrm{O}_{2}$ and $5 \%$ ethanol.

\section{Xanthohumol decreases intracellular oxidation}

The protective effect observed in Fig. 2 could be due to a decrease in the levels of ROS as a consequence of a scavenging activity of xanthohumol. We tested this hypothesis by incubating cells loaded with the redox-sensitive fluorochrome $\mathrm{H}_{2}$ DCFDA with xanthohumol and $\mathrm{H}_{2} \mathrm{O}_{2}$. This probe is able to diffuse freely into the cells through the plasma membrane where it is deacetylated to reduced dichlorofluorescein $\left(\mathrm{H}_{2} \mathrm{DCF}\right)$. This form is hydrophilic and becomes trapped inside cells due to impermeability of plasma membranes. In the presence of oxidants, or depending on the intracellular redox environment, $\mathrm{H}_{2}$ DCF is converted to oxidized fluorescent form, dichlorofluorescein (DCF), which can be measured in a flow cytometer upon excitation at $530 \mathrm{~nm}$ and emission at 485 $\mathrm{nm}$. As can be seen in Fig. 3, $5 \mathrm{mM} \mathrm{H}_{2} \mathrm{O}_{2}$ induced an increase of intracellular oxidation and, hence, higher fluo-

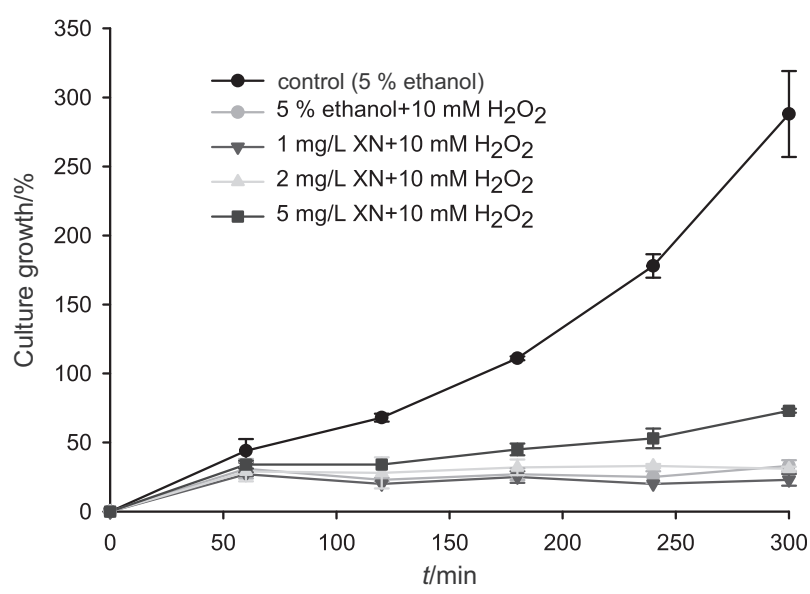

Fig. 2. Xanthohumol $(\mathrm{XN})$ protective effect on $S$. cerevisiae BY4741 cells under oxidative stress. Yeast cells in YPD cultures were coincubated at $30^{\circ} \mathrm{C}$ with $\mathrm{XN}(1,2$ or $5 \mathrm{mg} / \mathrm{L})$ and $10 \mathrm{mM}$ $\mathrm{H}_{2} \mathrm{O}_{2}$ for $5 \mathrm{~h}$. Culture growth was monitored by reading $A_{600 \mathrm{~nm}}$ at each time-point and the percentage of growth was calculated taking $0 \mathrm{~min}$ as reference. Data are the mean value \pm S.D. of three independent experiments rescence in $\mathrm{H}_{2}$ DCFDA-loaded cells (272 AU) than in non-treated cells (120 AU). Increasing concentrations of xanthohumol from 1 to 2 and $5 \mathrm{mg} / \mathrm{L}$ decreased the intracellular oxidation of cells induced by $\mathrm{H}_{2} \mathrm{O}_{2}$ in a dose-dependent manner (Fig. 3), which resulted in a lower fluorescence (250, 222 and $145 \mathrm{AU}$, respectively). Therefore, the antioxidant activity of xanthohumol observed in vitro is also present intracellularly when yeast cells are incubated with xanthohumol and $\mathrm{H}_{2} \mathrm{O}_{2}$.

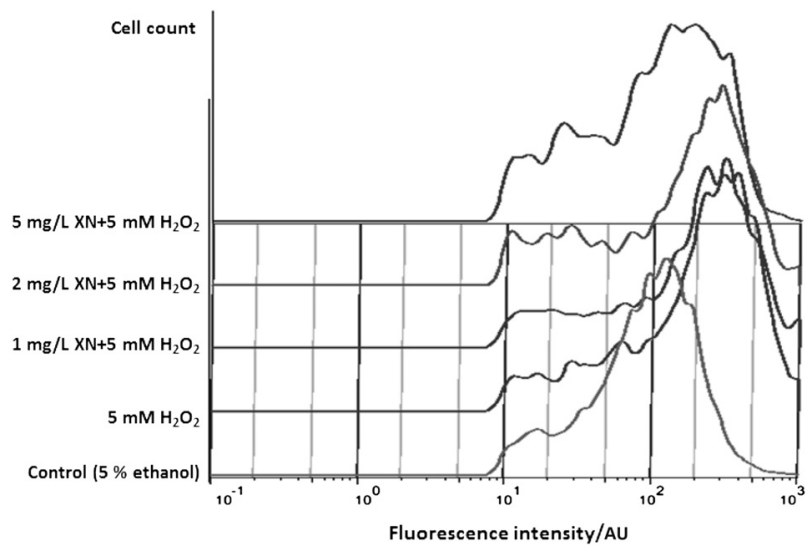

Fig. 3. Effect of xanthohumol $(\mathrm{XN})$ on the intracellular oxidation of S. cerevisiae BY4741 strain. Cells were loaded with $\mathrm{H}_{2} \mathrm{D}-$ CFDA and coincubated with $\mathrm{XN}$ and $5 \mathrm{mM} \mathrm{H}_{2} \mathrm{O}_{2}$ for $20 \mathrm{~min}$, followed by flow cytometry analysis of intracellular fluorescence. Fluorescence mean values presented were calculated using the FlowJo software (23). Data are from a representative experiment of at least three independent experiments. $\mathrm{H}_{2} \mathrm{D}$ CFDA=dichlorofluorescein diacetate

\section{Xanthohumol oxidation products determined by HPLC-DAD-ESI-MS/MS}

The oxidation reaction of the prenylated flavonoid xanthohumol was investigated in order to infer an oxidation induced by $\mathrm{H}_{2} \mathrm{O}_{2}$. The generated compounds were subsequently detected by high-performance liquid chromatography tandem mass spectrometry (HPLC-MS/MS). A 40-minute chromatographic run was performed and three major peaks were observed in HPLC-DAD and HPLC-MS/MS chromatograms (Fig. 4). The peak with retention time of 17.36 min showed a protonated molecule at $m / z=355.15$ in the ESI-Orbitrap mass spectrum and a UV spectrum with a maximum at $368 \mathrm{~nm}$. This is the most abundant peak in the chromatogram and corresponds to the xanthohumol fraction that was not oxidized (fragment ions at $m / z=179.03$ and 299.09 were observed). Two new peaks were detected as the oxidation products of xanthohumol, since they are not present in the blank/control assays. The new compound corresponding to the retention time of $12.64 \mathrm{~min}$ showed a protonated molecule at $m / z=369.13$ (Fig. 4). This oxidation product resulted from the net addition of one oxygen atom to xanthohumol and the loss of two hydrogen atoms. Collision-induced fragmentation of the selected ion yielded an abundance of prenyl cleavage fragments with $m / z=313.07$ $\left[\mathrm{MH}-\mathrm{C}_{4} \mathrm{H}_{8}\right]^{+}$. Accordingly, the compound was identified as the endoperoxyxanthohumol (EPOX, Fig. 5a), which 


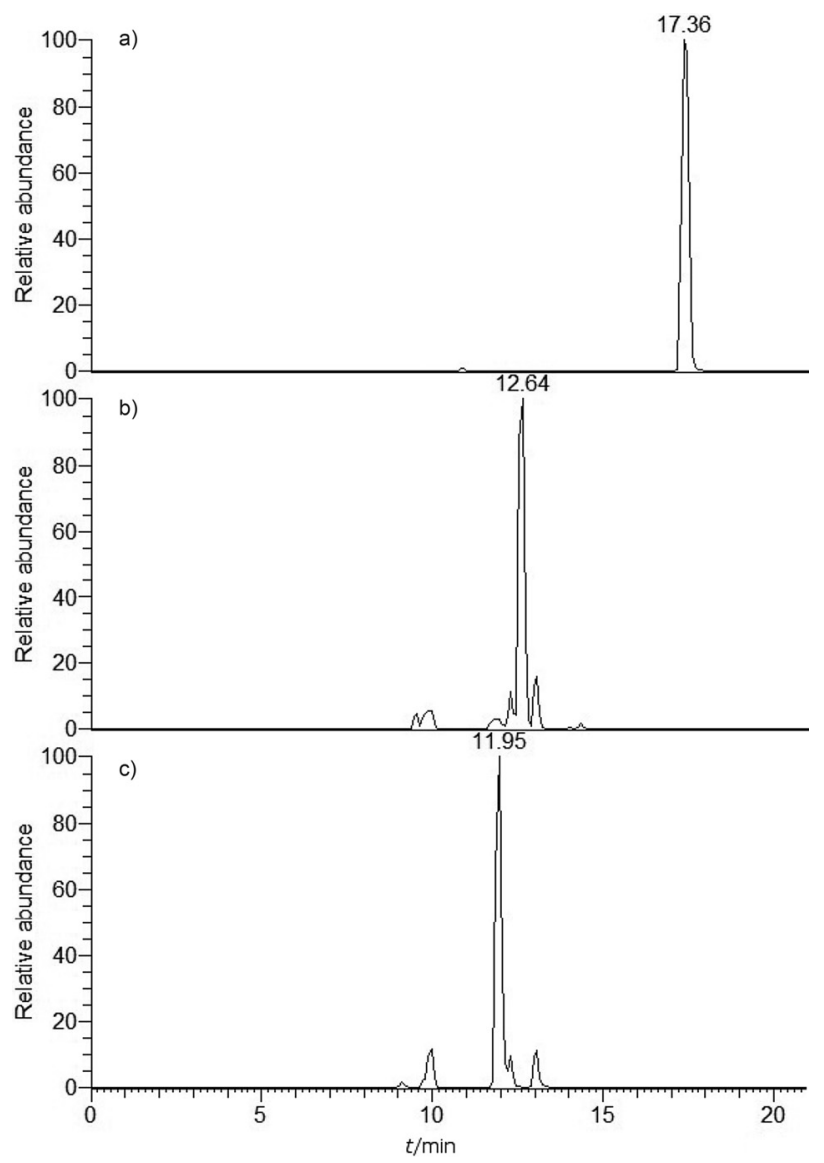

Fig. 4. Identification of xanthohumol $(\mathrm{XN})$ oxidation products induced by $\mathrm{H}_{2} \mathrm{O}_{2}$. The chromatograms are reconstructed at: a) $\mathrm{m} / \mathrm{z}=355.15$, b) $\mathrm{m} / \mathrm{z}=369.13$ and c) $\mathrm{m} / \mathrm{z}=387.14$<smiles>CCOc1ccccc1Oc1c(CC=C(C)C)c(O)cc2c1C(=O)C=C(c1ccc(O)cc1)OO2</smiles>

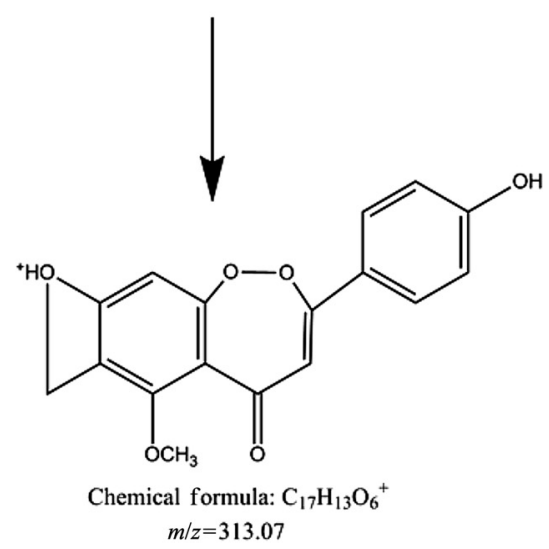

has been reported as a product formed after the treatment of xanthohumol with excess of peroxynitrite (28). The UV spectrum of $\operatorname{EPOX}\left(\lambda_{\max }=363 \mathrm{~nm}\right)$ and the lack of the base peak at $m / z=179$, which represents a fragment resulting from retro Diels-Alder reaction, point to the presence of this compound $\left(\mathrm{C}_{21} \mathrm{H}_{21} \mathrm{O}_{6}^{+}, m / z=369.13\right)$.

The observed $m / z=387.14$ for the peak with retention time of $11.95 \mathrm{~min}$ (Fig. 4) represents a gain in molecular mass of $32 \mathrm{Da}$, corresponding to an introduction of two oxygen atoms at the xanthohumol structure. The presence of the fragment ion at $m / z=301.11$ (Fig. 5b) suggested that the prenyl group could be attacked by the hydroperoxide. In effect, this fragment corresponds to the loss of the prenyl group, as shown in Fig. 5b. The double bond in the prenyl group has a higher electron density than the conjugated chalcone skeleton and is therefore more prone to an attack by the peroxyl radical. Consequently, addition of the peroxyl radical to the prenyl group gives rise to the cyclic peroxide with $m / z=387.14\left(\mathrm{C}_{21} \mathrm{H}_{23} \mathrm{O}_{7}^{+}\right)$. The presence of this oxidation product has not been reported for xanthohumol. However, several natural cyclic peroxides from marine sources have been tested for a broad range of activities including antiviral, antimalarial, antimicrobial activity and cytotoxicity (29).

\section{Xanthohumol protects yeast cells from DNA damage induced by $\mathrm{H}_{2} \mathrm{O}_{2}$}

The integrity of DNA is crucial to cells, but it is susceptible to damage induced by ROS (26). If a compound is able to prevent DNA damage it may have a potential benefit to cells and possibly to health in humans. The antioxidant activity of xanthohumol could contribute to genome<smiles>CCCCCOc1c(OC)cc(O)c(C(=O)/C=C/c2ccc(O)cc2)c1C1CC(C)(C)OO1</smiles>
$m / z=387.14$

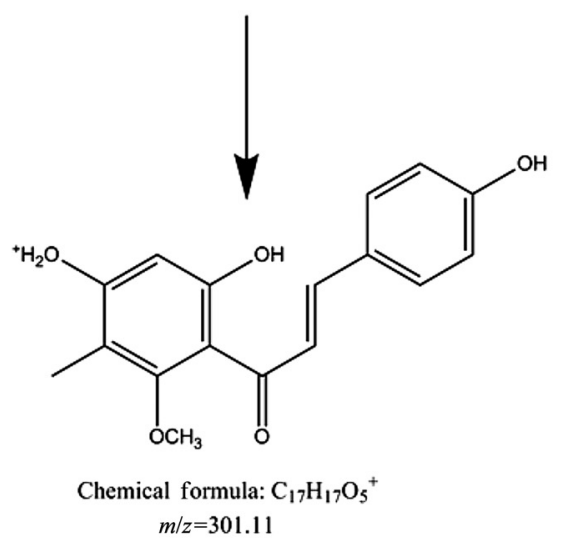

Fig. 5. Proposed structures of xanthohumol oxidation products with: a) $\mathrm{m} / \mathrm{z}=369.13$ and b) $\mathrm{m} / \mathrm{z}=387.14$ and the corresponding fragmentation processes 
protection in yeast cells, which, to our knowledge, has not been investigated before. The genome-protective effect of xanthohumol against oxidative DNA damage induced by $\mathrm{H}_{2} \mathrm{O}_{2}$ was evaluated using the yeast comet assay. The yeast comet assay is a well-established, simple, versatile, sensitive and inexpensive technique used to assess DNA oxidative damage quantitatively and qualitatively in eukaryotic cell populations (30-33). Yeast spheroplasts were incubated with different xanthohumol concentrations and $10 \mathrm{mM} \mathrm{H}_{2} \mathrm{O}_{2}$ in $\mathrm{S}$ buffer (containing $1 \mathrm{M}$ sorbitol) in order to maintain osmotic protection. Ethanol (5\% by volume) was present in all samples since xanthohumol was dissolved in ethanol. The DNA of the cells in the presence of ethanol alone was not significantly damaged (measured as comet tail length; Fig. 6), whereas $\mathrm{H}_{2} \mathrm{O}_{2}$ dramatically increased $(p<0.01)$ comet tail length. When xanthohumol was added, a decrease in comet tail length was observed at concentrations below $10 \mathrm{mg} / \mathrm{L}$ (Fig. 6). However, at the highest concentration of xanthohumol (10 $\mathrm{mg} / \mathrm{L}$ ), DNA damage was similar to that of cells incubated only with $10 \mathrm{mM} \mathrm{H}_{2} \mathrm{O}_{2}$. Therefore, dose-dependent antigenotoxic activity of xanthohumol is only observed at concentrations below $10 \mathrm{mg} / \mathrm{L}$.

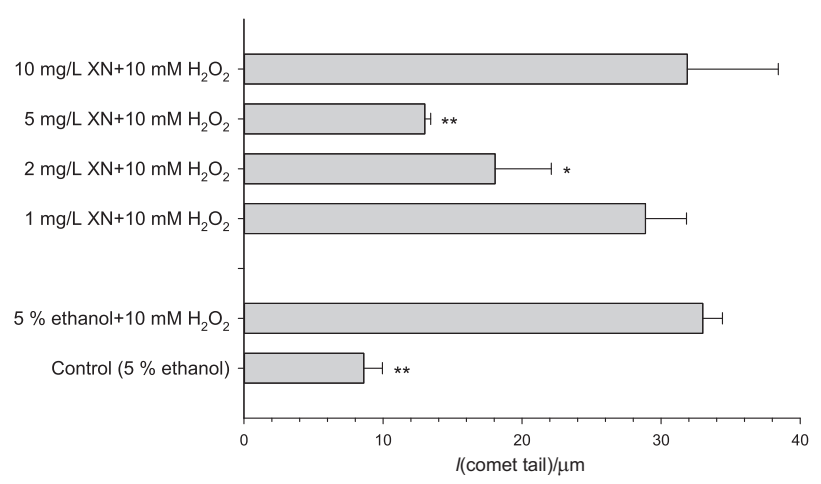

Fig. 6. Xanthohumol $(\mathrm{XN})$ protection against oxidative DNA damage of $S$. cerevisiae BY4741 strain induced by $\mathrm{H}_{2} \mathrm{O}_{2}$. Spheroplasts were coincubated with XN $(1,2,5$ or $10 \mathrm{mg} / \mathrm{L})$ and 10 $\mathrm{mM}$ of $\mathrm{H}_{2} \mathrm{O}_{2}$ for $20 \mathrm{~min}$, and DNA damage was assessed with the yeast comet assay. Cells incubated only with $5 \%$ ethanol (negative control) or $5 \%$ ethanol and $10 \mathrm{mM} \mathrm{H}_{2} \mathrm{O}_{2}$ (positive control) were included in the experiment. Tail lengths were measured for at least 20 comets per sample. Data are the mean value $\pm S$.D. of three independent experiments $\left({ }^{*} \mathrm{p}<0.05,{ }^{* *} \mathrm{p}<0.01\right)$

\section{Xanthohumol induces DNA damage}

Considering that xanthohumol was shown to be toxic to yeast cells only at concentrations higher than $10 \mathrm{mg} / \mathrm{L}$ (Figs. 1a and b) and at the same time protective at lower concentrations (Figs. 2, 3 and 6), it was hypothesized that xanthohumol could be genotoxic instead of protective at high concentrations. Cells were incubated with xanthohumol alone, without $\mathrm{H}_{2} \mathrm{O}_{2}$, and the DNA damage was assessed by the comet assay. As shown in Fig. 7, cells treated with xanthohumol at concentrations above $5 \mathrm{mg} / \mathrm{L}$ exhibited a statistically significant $(\mathrm{p}<0.001)$ increase in comet tail length when compared with cells treated only with ethanol ( $5 \%$ by volume). This strongly suggests that xanthohumol also has a genotoxic activity at higher concentrations. The genotoxic effect did not promote longer



Fig. 7. Effect of xanthohumol $(\mathrm{XN})$ on the genomic DNA of $S$. cerevisiae BY4742 strain. Spheroplasts were incubated with XN $(1,5,7.5,10$ or $20 \mathrm{mg} / \mathrm{L})$ for $20 \mathrm{~min}$ and DNA damage was analyzed with the yeast comet assay. Cells incubated only with $5 \%$ ethanol (negative control) or $5 \%$ ethanol and $10 \mathrm{mM} \mathrm{H}_{2} \mathrm{O}_{2}$ (positive control) were included in the experiment. Data are the mean value $\pm S$.D. of three independent experiments $\left({ }^{* * * *} p<0.001\right)$

comet tails at concentrations above $10 \mathrm{mg} / \mathrm{L}$ (Fig. 7), possibly due to the limited capacity of the genomic DNA to unwind and migrate during electrophoresis in the comet assay (30).

\section{Xanthohumol genotoxicity and prooxidant activity}

In an attempt to investigate the mechanism involved in xanthohumol genotoxicity observed at higher concentrations, a mutant yeast strain, yap1, sensitive to oxidative stress (34), was incubated with xanthohumol. The yap1 mutant strain is sensitive to oxidative stress because YAP1 encodes a transcription factor involved in the oxidative stress response triggering the transcription of genes encoding proteins required for scavenging and degrading ROS $(35,36)$. Strains yap 1 and the corresponding parental strain (BY4741) were cultured in rich medium in the presence of different concentrations of xanthohumol for 300 min and growth was monitored periodically by absorbance. Growth rate inhibition was calculated taking as reference the growth rate of the same strain without xanthohumol (Table 1). The growth of both strains was affected by xanthohumol, the yap 1 being more sensitive. Growth of the yap1 was significantly affected at all tested concentrations, while strain BY4741 was affected at 7.5 and 10 $\mathrm{mg} / \mathrm{L}$ of xanthohumol. Higher concentrations of xanthohumol affected both strains. The increased sensitivity of the yap 1 strain adds genetic evidence to the previous results, indicating that xanthohumol is prooxidant at high concentrations.

\section{Discussion}

Anticarcinogenic and antioxidant properties of xanthohumol present in Humulus lupulus L. have been reported before (3,5,9-14,37-39). However, scarce information is available on the effect of xanthohumol on yeast cells. This work presents a first approach to the study of antigenotoxic and genotoxic effects of xanthohumol on Saccharomyces cerevisiae cells focusing on the brewer's yeast physiology. The potential beneficial use of xanthohumol in human health has led beer manufacturers to 
Table 1. Growth rates of S. cerevisiae BY4741 and yap1 strains in the presence of xanthohumol

\begin{tabular}{|c|c|c|c|c|c|c|c|c|}
\hline & \multirow{2}{*}{ Control } & \multicolumn{3}{|c|}{$\gamma(\mathrm{XN}) /(\mathrm{mg} / \mathrm{L})$} & \multirow{2}{*}{ Control } & \multicolumn{3}{|c|}{$\gamma(\mathrm{XN}) /(\mathrm{mg} / \mathrm{L})$} \\
\hline & & 5 & 7.5 & 10 & & 5 & 7.5 & 10 \\
\hline & \multicolumn{4}{|c|}{ Growth rate/ $\mathrm{h}^{-1}$} & \multicolumn{4}{|c|}{ Growth rate inhibition/\% } \\
\hline BY4741 & 0.115 & 0.102 & 0.083 & 0.057 & - & 11.3 & $27.6^{*}$ & $49.8^{* *}$ \\
\hline yap1 & 0.099 & $0.057^{*}$ & $0.042^{*}$ & $0.019^{* *}$ & - & $42.1^{*}$ & $57.9^{* *}$ & $80.3^{* *}$ \\
\hline
\end{tabular}

Inhibition of growth was calculated as percentage of growth rate decrease of each strain taking as reference the control culture without xanthohumol $(X N)$. Growth rates are the mean value of three independent experiments $\left({ }^{*} p<0.05\right.$ and $\left.{ }^{* *} p<0.01\right)$

produce beer with higher contents of this compound. Generally, in studies on xanthohumol beer enrichment, the effect of xanthohumol concentration in yeast is disregarded, only seeking the parameters that can lead to higher xanthohumol concentrations in the final product $(15,16,40)$. However, addition of xanthohumol during brewing could affect negatively the yield and quality of beer due to the effects this compound could promote in yeast cells. Therefore, the knowledge of the mechanisms of biological activity of xanthohumol can help producers to circumvent the potential deleterious effects on brewer's yeasts. Here we show evidence supporting that at xanthohumol concentrations above $5 \mathrm{mg} / \mathrm{L}$ the loss of viability is due to a prooxidant activity, which affects the genome integrity. However, we also show that low levels of xanthohumol (below $5 \mathrm{mg} / \mathrm{L}$ ) protect yeast cells from oxidative stress and oxidative DNA damage induced by $\mathrm{H}_{2} \mathrm{O}_{2}$ in a dose-dependent manner. Intracellular oxidation state, as measured in vivo with the redox-sensitive probe $\mathrm{H}_{2} \mathrm{DCF}$ $\mathrm{DA}$, also decreases in a dose-dependent manner with xanthohumol in this concentration range.

The results presented in Figs. 1a and b demonstrate that yeast cells are affected by xanthohumol and hence, fermentation can be highly influenced by the addition of this compound in the previous industrial steps. For this reason, forthcoming investigation on the production of xanthohumol-enriched beer should include monitoring of xanthohumol concentration during fermentation in order to improve fermentation performance. These results are in agreement with those reported by Magalhães et al. (19) where viability slightly decreased after the addition of 10 $\mathrm{mg} / \mathrm{L}$ of xanthohumol at the beginning of fermentation. The differences with our study, namely in the fermentation conditions at $4{ }^{\circ} \mathrm{C}$ for one week and the yeast species (Saccharomyces pastorianus), might explain the less intense response in viability. Moreover, lower temperatures can decrease xanthohumol solubility and consequent bioavailability since it is only slightly soluble in aqueous medium.

In the same study, Magalhães et al. (19) report that the increase of yeast vitality (fermentative capacity) could be ascribed to the protective antioxidant activity of xanthohumol. Accordingly, xanthohumol has been reported to be an effective antioxidant (8) and free radical scavenger $(5,37)$. Results of our study remain in line with these reports for concentrations below $5 \mathrm{mg} / \mathrm{L}$, assessed by both, viability assays (Fig. 2) and flow cytometry (Fig. 3). In this range of concentrations we report that xanthohumol has antigenotoxic activity, which correlates with the antioxidant activity reported here (Fig. 3, $r_{\mathrm{s}}=0.90$ ) and elsewhere
$(5,8,37)$, and with the prevention of amino-3-methylimidazo[4,5-f] quinoline-induced DNA damage in liver cells (41). The antioxidant activity of xanthohumol was evidenced by the identification of two major oxidation products of xanthohumol molecule induced by $\mathrm{H}_{2} \mathrm{O}_{2}$ (Figs. 4 and 5).

Concentrations of xanthohumol above $5 \mathrm{mg} / \mathrm{L}$ provoked the opposite effect, leading to a slower growth rate (Table 1) and genotoxicity (Fig. 6). When a yeast mutant sensitive to oxidative stress (yap1) was used, the decrease in growth rate in the presence of xanthohumol was even higher (Table 1). This is also in accordance with previous studies showing that xanthohumol was able to induce intracellular ROS, leading to a decrease of cell viability and induction of apoptosis in several cancer cell lines $(9,42)$. Flavonoids with a phenol B ring are able to form phenoxyl radicals, which catalyze glutathione (GSH) or nicotinamide adenine dinucleotide (NADH) oxidation and consequent generation of ROS (42). Similarly, xanthohumol has an open C-ring with a hydroxyl group on the B-ring that may support the production of phenoxyl radical and ROS production. Prooxidant activity also appears to be related to the presence of transition metals (such as iron and copper), peroxidases and high flavonoid concentrations, increasing the formation of $\mathrm{Fe}^{2+}$ and $\mathrm{Cu}^{+}$that react with $\mathrm{H}_{2} \mathrm{O}_{2}$ in the Fenton reaction $(7,43)$.

Taken together, our results strongly suggest that xanthohumol has a dose-dependent dual effect on yeast cells: at low concentrations it is antigenotoxic, whereas at high concentrations it becomes genotoxic. In vitro antioxidant activity also revealed a mild antioxidant activity that correlates with this property. For flavonoids, this effect can be ascribed to the prooxidant activity at elevated doses, combined with the agents that induce oxidative damage (42). These results are in accordance with the denominated Janus effect proposed for substances with dual effect (44). These results agree qualitatively with a recent finding that xanthohumol protects mammalian cancer cells at low concentrations, while doses higher than $1.8 \mathrm{mg} / \mathrm{L}$ had a detrimental effect (18).

\section{Conclusions}

This work presents the first approach to the study of antigenotoxic and genotoxic effects of xanthohumol on Saccharomyces cerevisiae, contributing to an optimized utilization of xanthohumol in the production of xanthohumol-enriched beer and reinforcing the beneficial and harmful effects of this compound on yeast cells. 
Xanthohumol protects yeast cells from oxidative stress and oxidative DNA damage induced by $\mathrm{H}_{2} \mathrm{O}_{2}$, in a dose-dependent manner at concentrations up to $5 \mathrm{mg} / \mathrm{L}$. The protective effect of xanthohumol involves a ROS scavenging mechanism with a consequent decrease of intracellular oxidation of cells. However, once a concentration threshold $(5 \mathrm{mg} / \mathrm{L})$ has been reached, xanthohumol triggers the opposite effect leading to a slower growth rate and genotoxicity. The evaluation of the impact of xanthohumol on yeast mutants affected by oxidative stress (yap1) proved that xanthohumol toxicity is mediated by oxidative stress, indicating its prooxidant effect at concentrations higher than $5 \mathrm{mg} / \mathrm{L}$.

\section{Acknowledgements}

This work was funded by FEDER through the Operational Programme for Competitiveness Factors - COMPETE and by National Funds through FCT - Foundation for Science and Technology, under the projects UID/ QUI/50006/2013 and NORTE-07-0124-FEDER-000069. DC wishes to acknowledge FCT for his PhD studentship (SFRH/BD/79939/2011). BJ acknowledges the support of FCT through project PTDC/AAC-AMB/120940/2010 'MYCOFAT'. DC wishes to acknowledge FCT for his PhD studentship (SFRH/BD/79939/2011). We thank Martin Biendl, from Hopsteiner (New York, NY, USA), for donating the xanthohumol and Cristina Ribeiro for help in flow cytometry analyses. Mass spectrometry analyses were conducted at CEMUP (Materials Centre of the University of Porto, Portugal).

\section{References}

1. Magalhães PJ, Guido LF, Cruz JM, Barros AA. Analysis of xanthohumol and isoxanthohumol in different hop products by liquid chromatography-diode array detection-electrospray ionization tandem mass spectrometry. J Chromatogr A. 2007; 1150:295-301.

http://dx.doi.org/10.1016/j.chroma.2006.08.019

2. Magalhães PJ, Vieira JS, Gonçalves LM, Pacheco JG, Guido LF, Barros AA. Isolation of phenolic compounds from hop extracts using polyvinylpolypyrrolidone: characterization by high-performance liquid chromatography-diode array detection-electrospray tandem mass spectrometry. J Chromatogr A. 2010;1217:3258-68. http://dx.doi.org/10.1016/j.chroma.2009.10.068

3. Magalhães PJ, Carvalho DO, Cruz JM, Guido LF, Barros AA. Fundamentals and health benefits of xanthohumol, a natural product derived from hops and beer. Nat Prod Commun. 2009;4:591-610.

4. Stevens JF, Page JE. Xanthohumol and related prenylflavonoids from hops and beer: to your good health! Phytochemistry. 2004;65:1317-30.

http://dx.doi.org/10.1016/j.phytochem.2004.04.025

5. Gerhäuser C. Beer constituents as potential cancer chemopreventive agents. Eur J Cancer. 2005;41:1941-54. http://dx.doi.org/10.1016/j.ejca.2005.04.012

6. Gerhäuser C, Alt AP, Klimo K, Knauft J, Frank N, Becker H. Isolation and potential cancer chemopreventive activities of phenolic compounds of beer. Phytochem Rev. 2002;1:369-77. http://dx.doi.org/10.1023/A:1026082325529

7. Cao G, Sofic E, Prior RL. Antioxidant and prooxidant behavior of flavonoids: structure-activity relationships. Free Radic
Biol Med. 1997;22:749-60.

http://dx.doi.org/10.1016/S0891-5849(96)00351-6

8. Miranda CL, Stevens JF, Ivanov V, McCall M, Frei B, Deinzer ML, Buhler DR. Antioxidant and prooxidant actions of prenylated and nonprenylated chalcones and flavanones in vitro. J Agric Food Chem. 2000;48:3876-84.

http://dx.doi.org/10.1021/jf0002995

9. Festa M, Capasso A, D'Acunto CW, Masullo M, Rossi AG, Pizza C, Piacente S. Xanthohumol induces apoptosis in human malignant glioblastoma cells by increasing reactive oxygen species and activating MAPK pathways. J Nat Prod. 2011;74:2505-13. http://dx.doi.org/10.1021/np200390x

10. Deeb D, Gao X, Jiang H, Arbab AS, Dulchavsky SA, Gautam SC. Growth inhibitory and apoptosis-inducing effects of xanthohumol, a prenylated chalone present in hops, in human prostate cancer cells. Anticancer Res. 2010;30:3333-9.

11. Drenzek JG, Seiler NL, Jaskula-Sztul R, Rausch MM, Rose SL. Xanthohumol decreases Notch1 expression and cell growth by cell cycle arrest and induction of apoptosis in epithelial ovarian cancer cell lines. Gynecol Oncol. 2011;122:396401.

http://dx.doi.org/10.1016/j.ygyno.2011.04.027

12. Zajc I, Filipič M, Lah TT. Xanthohumol induces different cytotoxicity and apoptotic pathways in malignant and normal astrocytes. Phytother Res. 2012;26:1709-13. http://dx.doi.org/10.1002/ptr.4636

13. Lust S, Vanhoecke B, Janssens A, Philippe J, Bracke M, Offner F. Xanthohumol kills B-chronic lymphocytic leukemia cells by an apoptotic mechanism. Mol Nutr Food Res. 2005; 49:844-50. http://dx.doi.org/10.1002/mnfr.200500045

14. Pan L, Becker H, Gerhäuser C. Xanthohumol induces apoptosis in cultured 40-16 human colon cancer cells by activation of the death receptor- and mitochondrial pathway. Mol Nutr Food Res. 2005;49:837-43. http://dx.doi.org/10.1002/mnfr.200500065

15. Wunderlich S, Zürcher A, Back W. Enrichment of xanthohumol in the brewing process. Mol Nutr Food Res. 2005;49:87481.

http://dx.doi.org/10.1002/mnfr.200500051

16. Magalhães PJ, Dostalek P, Cruz JM, Guido LF, Barros AA. The impact of a xanthohumol-enriched hop product on the behavior of xanthohumol and isoxanthohumol in pale and dark beers: a pilot scale approach. J Inst Brewing. 2008;114: 246-56. http://dx.doi.org/10.1002/j.2050-0416.2008.tb00335.x

17. Salmon JM. Interactions between yeast, oxygen and polyphenols during alcoholic fermentations: practical implications. LWT - Food Sci Technol. 2006;39:959-65. http://dx.doi.org/http://dx.doi.org/10.1016/j.lwt.2005.11.005

18. Blanquer-Rosselló MM, Oliver J, Valle A, Roca P. Effect of xanthohumol and 8-prenylnaringenin on MCF-7 breast cancer cells oxidative stress and mitochondrial complexes expression. J Cell Biochem. 2013;114:2785-94. http://dx.doi.org/10.1002/jcb.24627

19. Magalhães PJ, Carvalho AB, Gonçalves LM, Pacheco JG, Guido LF, Brányik $\mathrm{T}$, et al. The impact of xanthohumol on a brewing yeast's viability, vitality and metabolite formation. J Inst Brewing. 2011;117:368-76. http://dx.doi.org/10.1002/j.2050-0416.2011.tb00481.x

20. Oliveira R, Johansson B. Quantitative DNA damage and repair measurement with the yeast comet assay. Methods Mol Biol. 2012;920:101-9. http://dx.doi.org/10.1007/978-1-61779-998-3_8

21. CometScore (Comet scoring software), v. 1.5. TriTek Corp., Sumerduck, VA, USA; 2013. Available from: http://www.autocomet.com. 
22. Marques F, Azevedo F, Johansson B, Oliveira R. Stimulation of DNA repair in Saccharomyces cerevisiae by Ginkgo biloba leaf extract. Food Chem Toxicol. 2011;49:1361-6. http://dx.doi.org/http://dx.doi.org/10.1016/j.fct.2011.03.020

23. FlowJo (Single cell analysis), v. 10.0.7. FlowJo, LLC, Ashland, OR, USA; 2014. Available from: http://www.flowjo.com.

24. Xcalibur ${ }^{\mathrm{TM}}$ (Data acquisition and processing software), v. 2.2. Thermo Scientific, MA, USA; 2011. Available from: http:// www.thermoscientific.com/.

25. Wunderlich S, Wurzbacher M, Back W. Roasting of malt and xanthohumol enrichment in beer. Eur Food Res Technol. 2013;237:137-48 http://dx.doi.org/10.1007/s00217-013-1970-5

26. Halliwell B. Oxidants and human disease: some new concepts. FASEB J. 1987;1:358-64.

27. Miller NJ, Rice-Evans C, Davies MJ, Gopinathan V, Milner A. A novel method for measuring antioxidant capacity and its application to monitoring the antioxidant status in premature neonates. Clin Sci. 1993;84:407-12.

28. Stevens JF, Miranda CL, Frei B, Buhler DR. Inhibition of peroxynitrite-mediated LDL oxidation by prenylated flavonoids: the $\alpha, \beta$-unsaturated keto functionality of 2'-hydroxychalcones as a novel antioxidant pharmacophore. Chem Res Toxicol. 2003;16:1277-86. http://dx.doi.org/10.1021/tx020100d

29. Jung M, Kim H, Lee K, Park M. Naturally occurring peroxides with biological activities. Mini-Rev Med Chem. 2003;3: 159-65. http://dx.doi.org/10.2174/1389557033405313

30. Azevedo F, Marques F, Fokt H, Oliveira R, Johansson B. Measuring oxidative DNA damage and DNA repair using the yeast comet assay. Yeast. 2011;28:55-61. http://dx.doi.org/10.1002/yea.1820

31. Collins AR. The comet assay for DNA damage and repair: principles, applications, and limitations. Mol Biotechnol. 2004; 26:249-61. http://dx.doi.org/10.1385/mb:26:3:249

32. Dhawan A, Bajpayee M, Parmar D. Comet assay: a reliable tool for the assessment of DNA damage in different models. Cell Biol Toxicol. 2009;25:5-32. http://dx.doi.org/10.1007/s10565-008-9072-z

33. Liao W, McNutt MA, Zhu WG. The comet assay: a sensitive method for detecting DNA damage in individual cells. Methods. 2009;48:46-53. http://dx.doi.org/10.1016/j.ymeth.2009.02.016

34. Stephen DWS, Rivers SL, Jamieson DJ. The role of the YAP1 and YAP2 genes in the regulation of the adaptive oxidative stress responses of Saccharomyces cerevisiae. Mol Microbiol.
1995;16:415-23.

http://dx.doi.org/10.1111/j.1365-2958.1995.tb02407.x

35. Wu A, Wemmie JA, Edgington NP, Goebl M, Guevara JL, Moye-Rowley WS. Yeast bZip proteins mediate pleiotropic drug and metal resistance. J Biol Chem. 1993;268:18850-8.

36. Moye-Rowley WS, Harshman KD, Parker CS. Yeast YAP1 encodes a novel form of the jun family of transcriptional activator proteins. Genes Dev. 1989;3:283-92. http://dx.doi.org/10.1101/gad.3.3.283

37. Gerhäuser C, Alt A, Heiss E, Gamal-Eldeen A, Klimo K, Knauft J, et al. Cancer chemopreventive activity of Xanthohumol, a natural product derived from hop. Mol Cancer Ther. 2002;1:959-69.

38. Procházková D, Boušová I, Wilhelmová N. Antioxidant and prooxidant properties of flavonoids. Fitoterapia. 2011;82: 513-23. http://dx.doi.org/10.1016/j.fitote.2011.01.018

39. Strathmann J, Klimo K, Sauer SW, Okun JG, Prehn JHM, Gerhauser C. Xanthohumol-induced transient superoxide anion radical formation triggers cancer cells into apoptosis via a mitochondria-mediated mechanism. FASEB J. 2010;24: 2938-50. http://dx.doi.org/10.1096/fj.10-155846

40. Wunderlich S, Zürcher A, Back W. Xanthohumol in brewingimpact of malt, xanthohumol dosage, wort and storage temperature. Brewing Sci. 2012;65:7-15.

41. Ferk F, Huber WW, Filipič M, Bichler J, Haslinger E, Mišík $\mathrm{M}$, et al. Xanthohumol, a prenylated flavonoid contained in beer, prevents the induction of preneoplastic lesions and DNA damage in liver and colon induced by the heterocyclic aromatic amine amino-3-methyl-imidazo[4,5-f] quinoline (IQ). Mutat Res. 2010;691:17-22. http://dx.doi.org/10.1016/j.mrfmmm.2010.06.006

42. Galati G, O'Brien PJ. Potential toxicity of flavonoids and other dietary phenolics: significance for their chemopreventive and anticancer properties. Free Radic Biol Med. 2004;37: 287-303.

http://dx.doi.org/10.1016/j.freeradbiomed.2004.04.034

43. Laughton MJ, Halliwell B, Evans PJ, Hoult JRS. Antioxidant and pro-oxidant actions of the plant phenolics quercetin, gossypol and myricetin: effects on lipid peroxidation, hydroxyl radical generation and bleomycin-dependent damage to DNA. Biochem Pharmacol. 1989;38:2859-65. http://dx.doi.org/10.1016/0006-2952(89)90442-5

44. von Borstel RC, Higgins JA. Janus carcinogens and mutagens. Mutat Res. 1998;402:321-9. http://dx.doi.org/10.1016/S0027-5107(97)00312-6 